\title{
LITERASI KEUANGAN SERTA PENGGUNAAN PRODUK DAN JASA LEMBAGA KEUANGAN
}

\author{
Oleh: \\ Sri Lestari ${ }^{1)}$ \\ E-mail:cicimanajemen@gmail.com
}

\begin{abstract}
This study entitled: "Financial Literacy and Utility Products and Services Financial Institutions". The purpose of this research are: 1) Knowing and analyzing the financial literacy index of financial products and services to the students of the faculty of Economics and Business jenderal Soedirman University 2) Knowing and analyzing the utility index products and financial services to the students of Economics and Business Faculty; ; 3) Knowing and analyzing the causes and the high barriers to low index Financial Literacy and utility products and financial services among the students of the Faculty of Economics and Business Faculty; 4) Determine and analyze whether the effort made by Fiancial Service Autority, Financial Institutions and the Program to improve the financial literacy of students; 5) Provide input to the Financial Services Authority and the Program in preparing the financial literacy materials needed to improve students understanding of financial products and services. This research is a qualitative descriptive method analysis using informants population and students of the Faculty of Economics and Business UNSOED, the Financial Services Authority officials, managers of Studies, and Financial Institutions Officer.

The results showed that financial literacy index of financial institutions that exist in Indonesia at the FEB students Unsoed still low at only \$ 4.76 for students who are well literate and amounted to $95.24 \%$ in banking products and services. Causes and high barriers to low index of Literacy Financial and utility products and financial services among the students of the Faculty of Economics and Business UNSOED is: do not get the financial education of the family as a child (80\%), not taught in formal education as a child (77\%), not to get the material and a deep understanding of the subjects were obtained during the study (70\%), and the limited funds received from parents and therefore can not be used to invest in products and services of financial institutions (93\%). Therefore, the financial services authority need to be more intensive in propagating financial literacy program for students with conduct socialization activities continuously. While the Program need to improve financial learning with learning innovation, identifying subjects that are relevant to the Financial Literacy material, determine appropriate teaching methods and reviewing the curriculum back.
\end{abstract}

Keywords: Financial Literacy, Utility of financial institutions, Financial Services Authority

Pendahuluan

Financial literacy merupakan kesadaran dan pengetahuan tentang produk- produk keuangan, lembaga keuangan, dan konsep mengenai keterampilan dalam mengelola keuangan (Lisa $\mathrm{Xu}$ dan Bilal Zia, 2012) sedangkan menurut Otoritas 
Jasa keuangan (OJK) Literasi Keuangan adalah rangkaian proses atau aktivitas untuk meningkatkan pengetahuan (knowledge), keyakinan (confidence), keterampilan (skill) konsumen dan masyarakat luas sehingga mereka mampu mengelola keuangan dengan lebih baik. Dengan definisi ini diharapkan konsumen produk dan jasa keuangan maupun masyarakat luas diharapkan tidak hanya mengetahui dan memahami lembaga jasa keuangan serta produk dan jasa keuangan, melainkan juga dapat mengubah atau memperbaiki perilaku masyarakat dalam pengelolaan keuangan sehingga mampu meningkatkan kesejahteraan mereka.

Topik tentang literasi keuangan ini menjadi sangat penting dipertimbangkan oleh para ahli sejak adanya krisis ekonomi global tahun 2008. Para ahli menyampaikan pendapatnya bahwa terjadinya krisis ekonomi global yang bermula terjadi di Amerika Serikat disebabkan karena tingkat literasi keuangan masyarakat Amerika Serikat rendah. Pada saat itu rakyat Amerika Serikat sangat konsumtif melebihi kemampuan pendapatan yang diterimanya. Mereka mempunyai banyak hutang, belanja menggunakan kartu kredit dan menggunakan kredit perumahan. Kebiasaan rakyat Amerika Serikat ini menyebabkan lembaga keuangan yang memberikan kredit bangkrut akibat kehilangan likuiditasnya. Hal ini disebabkan piutang perusahaan kepada para kreditur telah dijaminkan kepada lembaga pemberi pinjaman. Akibatnya perusahaanperusahaan tersebut mengalami kebangkrutan juga karena tidak dapat membayar hutanghutangnya yang mengalami masa jatuh tempo pada waktu yang bersamaan. Kebangkrutan perusahaan-perusahaan finansial tersebut berimbas ke Bursa Saham Wall Street. Keadaan ini mempunyai efek domino yang akhirnya merambat ke sektor riil dan non keuangan di seluruh dunia.

Bertolak dari pengalaman dan keadaan tersebut negara-negara di dunia berusaha memberikan pendidikan melek keuangan pada rakyatnya, karena hal ini sangat penting. Orang yang mempunyai tingkat Literasi Keuangan yang rendah akan mudah dibohongi dalam menggunakan uangnya. Sebaliknya orang yang mempunyai tingkat Literasi Keuangan yang tinggi akan mampu memilih dan memanfaatkan produk dan jasa keuangan yang sesuai kebutuhan, memiliki kemampuan dalam melakukan perencanaan keuangan dengan lebih baik, terhindar dari aktivitas investasi pada instrumen keuangan yang tidak jelas, dan mendapatkan pemahaman mengenai manfaat dan risiko produk dan jasa keuangan..

Mengingat pentingnya masalah ini bagi masyarakat dunia, maka pada tahun 2012 diadakan Financial Literacy and Education Summit di Chicago. Berdasarkan barometer Global Finacial Literacy diumumkan peringkat melek keuangan dari 28 negara. Negara-negara Meksiko, Brazil, dan Amerika merupakan negara teratas yang keluarga-keluarganya banyak membicarakan masalah keuangan kepada anak-anaknya (finance.detik.com,2012). Di Indonesia OJK memandang perlu menjadikan Literasi Keuangan menjadi suatu program strategis yang bersifat nasional. Dengan mempertimbangkan rendahnya tingkat literasi keuangan di Indonesia (hanya sebesar 28,1 persen) dengan tingkat utilisasi produk lembaga keuangan sebesar 59,7 persen, sebagian besar berasal dari sektor perbankan., OJK berusaha meningkatkan financial literacy melalui program cetak biru Strategi Nasional Keuangan Inklusif (SNKI) yang diluncurkan pada 19 November 2013. Melalui strategi ini dilakukan berbagai upaya yang komprehensif dan sitematis untuk meningkatkan Indeks Literasi Keuangan maupun Indeks Utilitas Produk dan Jasa Keuangan masyarakat yang akan membawa masyarakat Indonesia memiliki Indeks Literasi yang tinggi (well literate). Sasaran pelaksanaan strategi SNKI 
ini adalah Ibu rumah tangga, UMKM, pelajar, mahasiswa, profesi, karyawan, dan para pensiunan.

Mahasiswa merupakan salah satu pihak yang menjadi proritas sasaran dan kegiatan Litersi Keuangan. Hal ini disebabkan mahasiswa dapat berperan sebagai agen perubahan. Sebagai golongan masyarakat yang intelektual peranan mahasiswa sangat dibutuhkan dan penting dalam perubahan bangsa. Mahasiswa dapat menggunakan teori yang di pelajarinya di kampus untuk menyelesaikan permasalahan yang terjadi di masyarakat. Mahasiswa diharapkan selalu berpikir kritis dalam menyelesaikan masalah yang ada di masyarakat dan dapat memberikan solusi. Disamping itu, setelah menyelesaikan pendidikannya di Perguruan Tinggi, mahasiswa juga akan terjun ke masyarakat dan melaksanakan tugasnya sebagai generasi penerus bangsa yang akan meneruskan dan menggantikan generasi sebelumnya untuk melakukan perubahan bangsa ke arah yang lebih baik dan maju. Oleh karena itu mahasiswa perlu dibekali dengan pemahaman tentang Literasi Keuangan dengan baik sehingga dapat membantu permasalahan di masyarakat dan menjadi bekal dirinya juga pada saat harus terjun ke masyarakat.

Mahasiswa Fakultas Ekonomi dan Bisnis UNSOED terutama pada semester akhir telah dibekali dengan berbagai pengetahuan dalam pengelolaan bisnis termasuk pengelolaan keuangan. Oleh karena itu diharapkan mempunyai pengetahuan tentang Literasi Keuangan dengan baik. Untuk mengetahui seberapa tinggi tingkat literasi keuangan dan utilitas mereka terhadap produk-produk lembaga keuangan, penyebab dan hambatanhambatannya, upaya yang telah dilakukan oleh OJK, Lembaga Keuangan dan Prodi serta materi Literasi keuangan apa saja yang dibutuhkan untuk meningkatkan pemahaman mahasiswa tentang Literasi Keuangan maka perlu dilakukan penelitian terhadap mahasiswa tersebut. Hasil penelitian ini dapat digunakan untuk mengukur tingkat Literasi Keuangan dan utilitas penggunaan produk dan jasa Lembaga Keuangan di kalangan mahasiswa pada umumnya dan digunakan sebagai bahan masukan bagi Otoritas Jasa Keuangan maupun program studi dalam menyusun materi Literasi Keuangan yang mencakup seluruh sektor jasa keuangan pada jenjang pendidikan pendidikan tinggi.

\section{Kerangka Teoritis}

Huston (2011) menggunakan parameter penilaian literasi keuangan dengan variabel keterampilan pengelolaan keuangan, pengetahuan investasi, dan perencanaan keuangan untuk menentukan tingkat ketrampilan pengelolaan keuangan dalam hal anggaran, tabungan, dan tanggung jawab atas penggunaan kredit. Orang dengan tingkat literasi keuangan rendah berpotensi untuk menjadi sasaran kejahatan keuangan. Mereka dapat ditipu berbagai jenis model investasi, diberi harapan mendapatkan bunga tinggi, namun ternyata tertipu. Orang dengan tingkat literasi keuangan yang rendah juga akan sulit untuk meningkatkan kualitas hidupnya karena saat sekarang kehidupan masyarakat tidak terlepas dari jasa keuangan. Apalagi saat ini dimana kita berada dalam perekonomian global.

Tahun 2015 Indonesia sudah berada dalam Masyarakat Ekonomi Asean. Dengan adanya MEA maka akan tercipta kesatuan pasar dan basis produksi yang akan membuat arus barang, jasa, investasi, modal dalam jumlah yang besar. Skilled labour menjadi tidak ada hambatan dari satu negara ke negara lainnya di kawasan Asia Tenggara. Menghadapi keadaan tersebut maka tingkat literasi keuangan masyarakat harus tinggi.

Topik tentang literasi keuangan merupakan hal yang baru. Penelitian- 
penelitian terdahulu tentang topik ini banyak dilakukan terhadap masyarakat secara umum untuk mengkaji literasi keuangan secara personal dalam upaya meningkatkan kesejahteraan masyarakat secara umum. Penelitian-penelitian tersebut dilakukan oleh Lusardi and Mitchell (2006), Shafi dan Medabesh (2012), Lusardi and Mitchell (2008), Lusardi et all (2010), Khaki dan Sangmi (2012), Willis (2011), Cnaan dan Handy (2012), Bruce dan Robinson (2010), Lisa Xu dan Bilal Zia (2012), Lusardi dan Mitchell (2014). Penelitian terdahulu dengan topik literasi keuangan pada UMKM masih sangat jarang ditemukan. Padahal penelitianpenelitian dengan topik ini pada pelaku UMKM sangat penting untuk dilakukan dalam upaya mengembangkan UMKM di Indonesia. Hal ini disebabkan UMKM mempunyai peran yang strategis dan menjadi tulang punggung dalam perekonomian Indonesia.

Debat teori yang telah dilakukan oleh para ahli di berbagai negara juga membuktikan bahwa masalah keuangan merupakan masalah paling penting yang dihadapi UMKM seperti disebutkan dalam debat-debat teori Levy (1993 ), Bandari dan Bajpai (2005), Thevaruban (2009), Ganesan, (1982, 2000); Gunatilaka (1997), Laxmi dan Kumar, 1999) dalam Suwastika Naidu and Anand Chand (2011). Hasil penelitian serupa juga terlihat di Malaysia. Menurut Chee (1986), banyak pemilik UKM Malaysia menemukan kesulitan dalam mendapatkan pinjaman karena kurangnya modal. Penelitian lain seperti Boocok dan Wahab (1999), Ede et al. (2000) dan Rose et al. (2006) menekankan bahwa pemilik UKM di Malaysia menghadapi kendala keuangan karena mereka tidak memiliki kompetensi khusus di bidang keuangan. Dalam konteks negara-negara Kepulauan Pasifik Selatan, penelitian telah dilakukan oleh Yusuf (1995), Baldacchino $(1995,1999)$ dan Pandaram dan Amosa (2010) yang juga menemukan bukti bahwa masalah keuangan merupakan masalah krusial yang dihadapi oleh UMKM.

Perry dan Moris (2005) memasukkan masalah financial literacy ini dalam ranah financial management behavior. Penelitian Perry dan Moris (2005) menguji hubungan antara Locus of Control eksternal (LOC), pengetahuan keuangan, pendapatan dengan perilaku manajemen keuangan yang bertanggungjawab, hubungan antara pengetahuan keuangan dengan perilaku manajemen keuangan yang bertanggungjawab yang dimediasi oleh LOC eksternal, hubungan antara pendapatan dengan perilaku manajemen keuangan yang bertanggung jawab yang dimediasi oleh LOC eksternal, serta hubungan antara LOC dan perilaku manajemen keuangan yang bertanggung jawab dan antara pendapatan dan perilaku manajemen keuangan yang bertanggung jawab yang dimoderasi oleh variabel etnis. Peneliti lain yang menghubungkan hal ini dengan financial management behavior adalah Hilgert et all (2003), Hira dan Mugeda (1999), O’Neill et all (1999).

\section{Metod Riset}

Lokasi penelitian ini dilakukan di Fakultas Ekonomi Dan Bisnis UNSOED Purwokerto. Populasi dan informan dalam penelitian ini adalah mahasiswa Fakultas Ekonomi dan Bisnis UNSOED, Pejabat Otoritas Jasa Keuangan, para pengelola Program Studi, serta Pejabat Lembaga Keuangan yang diambil dengan metode purposive sample dengan kriteria mahasiswa Fakultas Ekonomi dan Bisnis UNSOED yang telah menempuh pendidikan selama 4 semester. Informan selanjutnya ditentukan dengan metode snowball sampling.

Berdasarkan strategi nasional literasi keuangan Indonesia, literasi keuangan 
masyarkat diklasifikasi dalam 4 tingkatan, yaitu:
a. Well Literate
Memiliki pengetahuan dan keyakinan tentang lembaga jasa keuangan serta produk dan jasa keuangan, termasuk fitur, manfaat dan risiko, hak dan kewajiban terkait produk dan jasa keuangan, serta memiliki keterampilan dalam menggunakan produk dan jasa keuangan.

\section{b. Sufficient Literate}

Memiliki pengetahuan dan keyakinan tentang lembaga jasa keuangan serta produk dan jasa keuangan, termasuk fitur, manfaat dan risiko, hak dan kewajiban terkait produk dan jasa keuangan.

c. Less Literate

Hanya memiliki pengetahuan tentang lembaga jasa keuangan, produk dan jasa keuangan

\section{d. Not Literate}

Tidak memiliki pengetahuan dan keyakinan tentang lembaga jasa keuangan serta produk dan jasa keuangan, serta tidak memiliki keterampilan dalam menggunaan produk dan jasa keuangan.

Indeks Literasi Keuangan merupakan parameter atau indikator yang menunjukkan tingkat pengetahuan, keterampilan, dan keyakinan mahasiswa terkait lembaga keuangan serta produk dan jasanya. Selain itu indeks literasi keuangan juga memberikan informasi mengenai tingkat pengetahuan mahasiswa terhadap fitur, manfaat, dan risiko, hak dan kewajiban mereka sebagai pengguna produk. Indeks Utilitas Produk dan Jasa Keuangan merupakan parameter atau indikator untuk mengukur seberapa banyak mahasiswa memanfaatkan produk dan jasa keuangan.

Penelitian ini menggunakan pendekatan kualitatif dengan teknik pengumpulan data melalui in-depth interview, kuesioner dan teknik analisis menggunakan analisis Deskriptif Kualitatif. Analisis deskriptif kualitatif yaitu dengan memberikan ulasan atau interpretasi terhadap data yang diperoleh sehingga menjadi lebih jelas dan bermakna dibandingkan dengan sekedar angka-angka. Langkahlangkahnya adalah reduksi data, penyajian data dengan bagan dan teks, kemudian penarikan kesimpulan.

\section{Pembahasan Dan Kesimpulan}

\section{a. Pembahasan}

\section{1) Indeks Literasi Keuangan serta indeks utilitas produk dan jasa keuangan pada mahasiswa Fakultas Ekonomi dan Bisnis UNSOED.}

Indeks Literasi Keuangan dan Utilitas berkaitan dengan lembaga keuangan yang ada di Indonesia pada umumnya, pada mahasiswa FEB UNSOED dapat dijelaskan pada gambar 1. dan 3 .

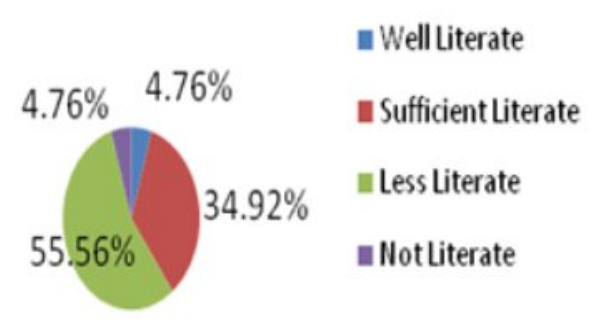

\section{Gambar 1. Indeks Literasi keuangan Mahasiswa FEB UNSOED}

Dari hasil survei yang dilakukan terhadap 100 responden diketahui bahwa hanya sebesar 4,76 mahasiswa yang well literate (gambar 2). Hal ini berarti hanya 5 mahasiswa dari 100 mahasiswa yang disurvei memiliki pengetahuan yang baik tentang lembaga keuangan serta produk dan jasanya, termasuk manfaat, risiko serta hak dan kewajibannya. Sementara sisanya tergolong "sufficient literate" (34,9 persen), "less 
literate" (55,56 persen), dan "not literate" (4,76 persen).

"Sufficient Literate" adalah masyarakat yang memiliki pengetahuan dan keyakinan tentang lembaga jasa keuangan serta produk dan jasa keuangan, termasuk fitur, manfaat dan risiko, hak dan kewajiban terkait produk dan jasa keuangan. "Less Literate" adalah masyarakat yang hanya memiliki pengetahuan tentang lembaga jasa keuangan, produk dan jasa keuangan. Sedangkan "Not Literate" yaitu masyarakat yang tidak memiliki pengetahuan dan keyakinan tentang lembaga jasa keuangan serta produk dan jasa keuangan, serta tidak memiliki keterampilan dalam menggunakan produk dan jasa keuangan.

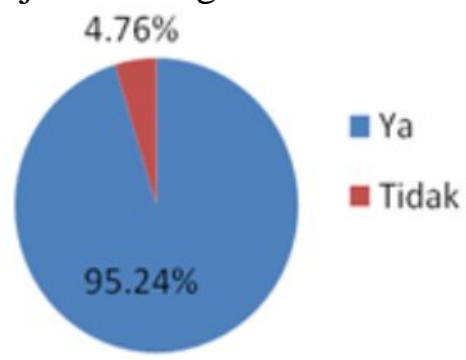

Gambar 2. Indeks utilitas produk dan jasa keuangan Indonesia

Indeks utilitas Produk dan Jasa Keuangan merupakan parameter atau indikator untuk mengukur seberapa banyak mahasiswa yang memanfaatkan produk dan jasa keuangan. Survei Literasi Keuangan terhadap mahasiswa FEB menunjukan bahwa Indeks Utilitas Produk dan Jasa Keuangan pada mahasiswa FEB sebesar 95,24\% (gambar 3). Hal ini berarti sebanyak 93 mahasiswa memanfaatkan produk dan jasa lembaga keuangan. Dari bukti ini diketahui bahwa mahasiswa memanfaatkan produk dan jasa lembaga keuangan tanpa disertai dengan pengetahuan yang cukup tentang produk dan jasa lembaga keuangan tersebut. Ini dibuktikan dengan indeks literasi keuangan yang rendah.
Gambar 3 menunjukkan Indeks Literasi Keuangan Produk dan Jasa Perbankan. Berdasarkan gambar 3 dapat diketahui Indeks Literasi mahasiswa FEB yang tergolong well literate terhadap industri perbankan menunjukkan angka 6,35persen. Hal ini berarti sebanyak 6,35 persen mahasiswa memiliki pengetahuan dan keyakinan terhadap lembaga perbankan, produk dan jasa perbankan, serta memiliki keterampilan dalam menggunakan produk dan jasa perbankan. Indeks ini pun menunjukkan tingkat yang rendah karena berarti hanya sebanyak 7 mahasiswa dari 100 mahasiswa yang memahami betul tentang produk dan jasa perbankan.

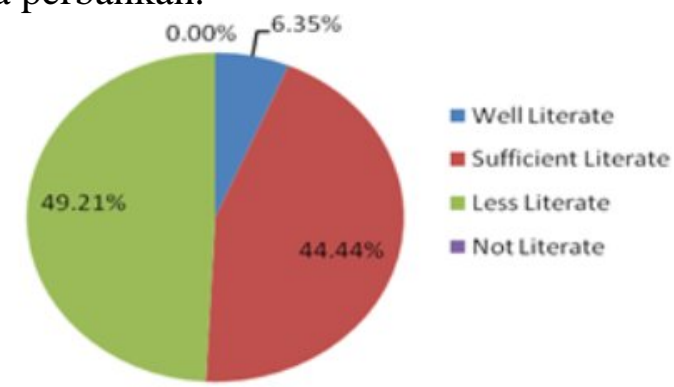

Gambar 3. Indeks Literasi Keuangan Produk dan Jasa Perbankan

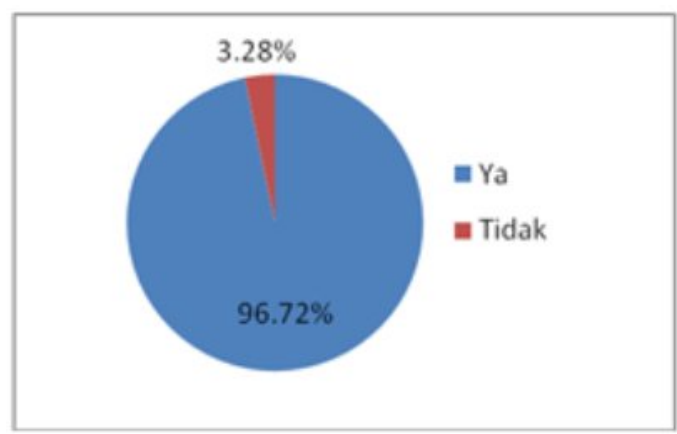

Gambar 4. Indeks Utilitas Produk dan Jasa Perbankan

Jika membandingkan indeks literasi dan indeks utilitas produk dan jasa perbankan dapat ditemukan hal yang menarik. Berdasar gambar 4 dapat diketahui bahwa utilitas produk dan jasa perbakan oleh mahasiswa FEB sebesar $96,72 \%$, yang berarti sebanyak 
96,72\% mahasiswa menggunakan produk dan jasa perbankan. Hasil survei tentang Literasi Keuangan serta utilitas produk dan jasa perbankan juga membuktikan bahwa sebagian besar mahasiswa memanfaatkan produk dan jasa perbankan tanpa disertai dengan pemahaman yang memadai akan produk dan jasa lembaga perbankan tersebut.

Gambar 5 menunjukkan indeks Literasi Keuangan produk dan jasa asuransi di kalangan mahasiswa FEB. Indeks Literasi Keuangan tersebut menunjukkan bahwa sebanyak $4,76 \%$ mahasiswa well literate terhadap industri peransurasian.

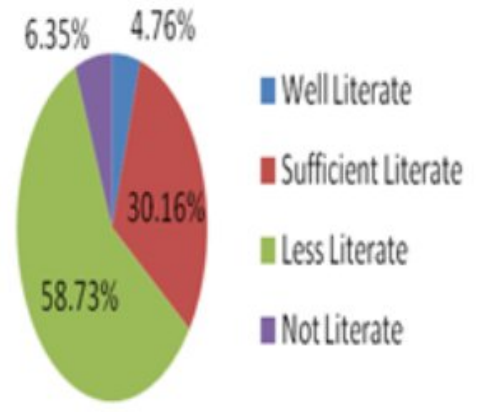

Gambar 5. Inteks Literasi Keuangan Produk dan Jasa Perasuransian

Hal ini dapat disimpulkan baru sebesar 4,76\% mahasiswa yang memahami asuransi. Jika dilihat dari tingkat utilitas produk dan jasa asuransi pada gambar 7 dapat diketahui bahwa sebanyak $62,90 \%$ mahasiswa menggunakan produk asuransi. Sama halnya dengan yang terjadi pada lembaga perbankan, demikian juga pada produk dan jasa asuransi, banyak masyarakat yang menggunakan produk dan jasa asuransi tanpa mempunyai pemahaman yang memadai akan produk dan jasa tersebut.

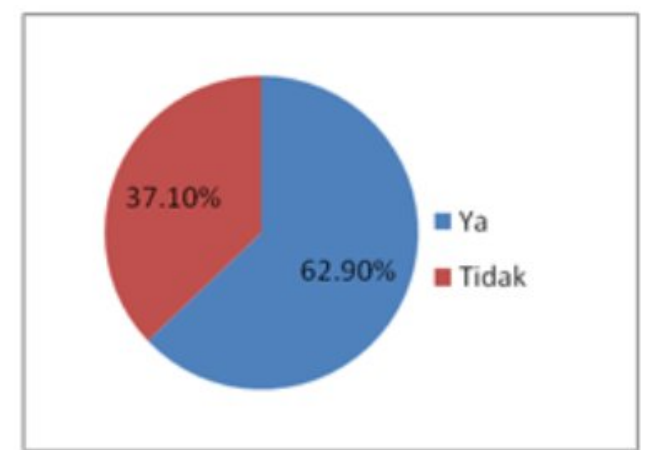

Gambar 6. Indeks Utilitas Produk dan Jasa Perasuransian

Hasil survei indeks Literasi Keuangan Produk dan Jasa Lembaga Pembiayaan terhadap mahasiswa FEB UNSOED menunjukkan bahwa hanya sebesar $4,76 \%$ mahasiswa FEB yang well Literate, dan terdapat 19,05\% mahasiswa FEB belum mengenal industri pembiayaan (gambar 7). Hal ini menunjukkan keadaan yang memprihatinkan mengingat responden adalah mahasiswa Fakultas Ekonomi dan Bisnis semester akhir.

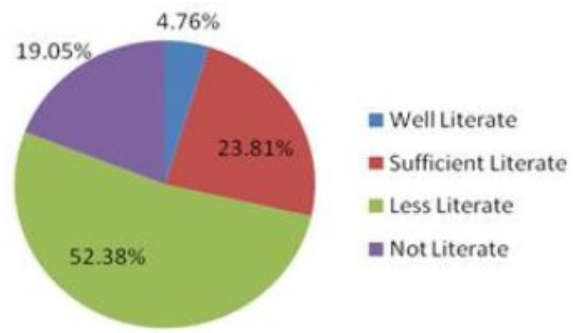

Gambar 7. Indeks Literasi Keuangan Produk dan Jasa Lembaga Pembiayaan

Gambar 8 menunjukkan utilitas produk dan jasa lembaga pembiayaan. Berdasarkan gambar 8 diketahui sebanyak $34,92 \%$ mahasiswa memanfaakan produk dan jasa lembaga pembiayaan, sedangkan sebanyak 65,08 persen tidak memanfaatkan produk dan jasa lembaga pembiayaan. 


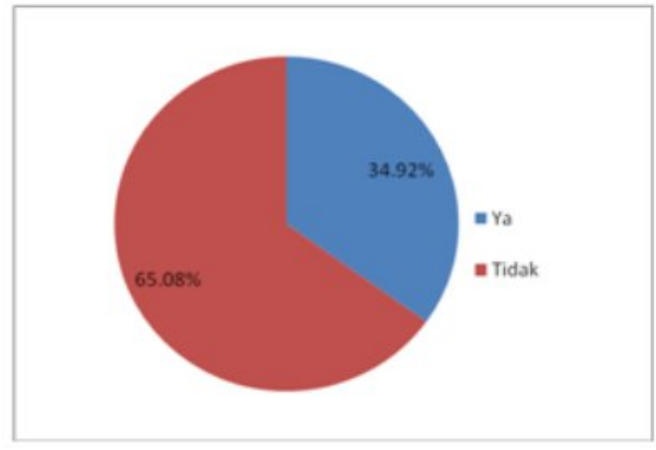

Gambar 8. Indeks utilitas Produk dan Jasa lembaga Pembiayaan

Gambar 9 menunjukkan Indeks Literasi Keuangan Produk dan Jasa Pasar Modal mahasiswa FEB UNSOED. Berdasarkan gambar 10 diketahui sebanyak 7,94\% mahasiswa well literate dan sebanyak $14,29 \%$ telah memanfaatkan pasar modal. Hal ini menunjukkan ada mahasiswa yang telah mempraktekan ilmu pasar modal yang telah dimiliki dan diperoleh selama menempuh pendidikan di FEB. Dari gambar 10 kita ketahui bahwa dari sebanyak 100 orang responden yang bersal dri mahasiswa FEB, ada 56 0rang sendiri yang tidak memiliki pengetahuan sama sekali tentang pasar modal. Hal ini kontradiktif mengingat responden belajar di Fakultas Ekonomi dan Bisnis, sedangkan trend ekonomi sekarang tidak lepas dari pasr modal. Keadaan ini harus benar-benar menjadi perhatian pihak fakultas dan pengelola program studi.

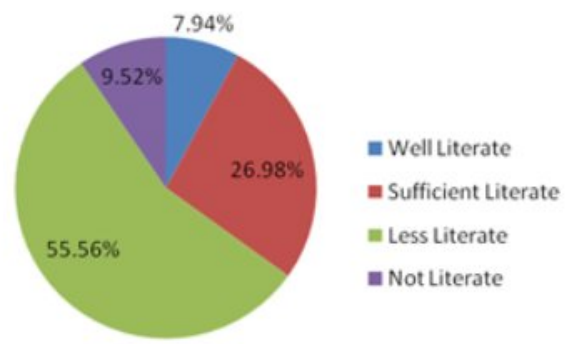

Gambar 9. Indeks Literasi Keuangan Produk dan Jasa Pasar Modal

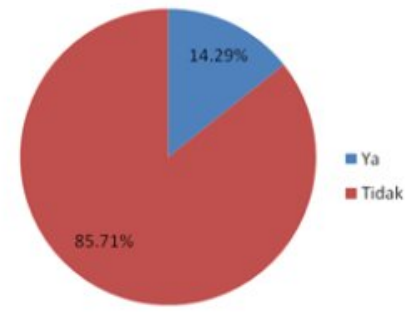

Gambar 10. Utilitas Produk dan Jasa Pasar Modal

Jika dilihat dari penggunaan produk dan jasa pasar modal pada gambar 11 terlihat ada 15 mahasiswa dari 100 mahasiswa yang telah menggunakan produk pasar modal. Berdasarkan wawancara mendalam yang dilakukan diketahui bahwa ke 15 mahasiswa ini telah mempraktekan melakukan investasi pada pasar modal. Keahlian yang mereka miliki mereka peroleh dari mata kuliah praktikum pasar modal yang telah diambilnya dan juga karena mengikuti kegiatan yang telah dlakukan orang tua dan keluarganya.

2) Analisis tentang penyebab dan hambatan tinggi rendahnya indeks Literasi Keuangan dan utilitas produk dan jasa keuangan di kalangan mahasiswa Fakultas Ekonomi dan Bisnis UNSOED.

Tabel 1. Tingkat well literate pada jenis literasi keuangan mahasiswa FEB Unsoed

\begin{tabular}{llc}
\hline No & $\begin{array}{l}\text { Jenis Literasi uang } \\
\text { Keuangan }\end{array}$ & $\begin{array}{c}\text { Well Literate } \\
(\%)\end{array}$ \\
\hline 1 & $\begin{array}{l}\text { Lembaga Keuangan } \\
\text { yang ada di Indonesia }\end{array}$ & 4,76 \\
2 & $\begin{array}{l}\text { Produk dan jasa } \\
\text { perbankan }\end{array}$ & 6,35 \\
3 & $\begin{array}{l}\text { Produk dan jasa } \\
\text { perasuransian }\end{array}$ & 4,76 \\
4 & $\begin{array}{l}\text { Produk dan jasa } \\
\text { lembaga pembiayaan }\end{array}$ & 4,76 \\
5 & $\begin{array}{l}\text { Produk dan jasa } \\
\text { pasar modal }\end{array}$ \\
\hline
\end{tabular}


Berdasar tabel 1 diketahui bahwa ratarata indeks literasi keuangan pada semua jenis produk dan jasa lembaga keuangan pada mahasiswa Fakultas Ekonomi dan Bisnis UNSOED tergolong rendah. Hasil kuesioner menunjukkan penyebab keadaan ini adalah karena tidak mendapatkan pendidikan keuangan dari keluarga sejak kecil $(80 \%)$, tidak diajarkan di pendidikan formal sejak kecil (77 \%), tidak mendapatkan materi dan pemahaman yang dalam dari mata kuliah yang diperoleh selama kuliah (70\%), serta terbatasnya dana yang diterima dari orang tua sehingga tidak dapat digunakan untuk berinvestasi pada produk dan jasa lembaga keuangan (93\%)

Tabel 2. Tingkat utilitas produk dan jasa keuangan mahasiswa FEB UNSOED

\begin{tabular}{llc}
\hline No & $\begin{array}{l}\text { Utilitas produk dan } \\
\text { jasa keuangan }\end{array}$ & $\begin{array}{l}\text { Indeks } \\
\text { utilitas } \\
\text { produk dan } \\
\text { jasa } \\
\text { keuangan } \\
(\%)\end{array}$ \\
\hline 1 & $\begin{array}{l}\text { Lembaga Keuangan } \\
\text { yang ada di }\end{array}$ & 95,24 \\
& $\begin{array}{l}\text { Indonesia } \\
\text { Produk dan jasa }\end{array}$ & 96,72 \\
3 & $\begin{array}{l}\text { perbankan } \\
\text { Produk dan jasa } \\
\text { perasuransian }\end{array}$ & 62,90 \\
4 & $\begin{array}{l}\text { Produk dan jasa } \\
\text { lembaga } \\
\text { pembiayaan } \\
\text { Produk dan jasa } \\
\text { pasar modal }\end{array}$ & 14,29 \\
\hline
\end{tabular}

Jika dilihat dari penggunaan terhadap produk lembaga keuangan menunjukkan tingkat utilitas yang tinggi pada produk produk dan jasa perbankan sebesar 96,72 persen dan Lembaga Keuangan yang ada di Indonesia secara umum sebesar 95,24 persen. Berdasarkan wawancara mendalam dengan mahasiswa diketahui bahwa penggunaan produk perbankan ini lebih banyak berupa layanan jasa perbankan untuk pembayaran biaya pendidikan, penggunaan ATM, transfer uang bulanan dari orang tua dan dalam bentuk tabungan. Jadi mereka menggunakan produk perbankan secara rutin untuk operasional mereka tanpa berusaha mengetahui secara mendalam tentang produk dan jasa perbankan. Hal inilah yang menyebabkan indeks utilitas terhadap produk dan jasa lembaga perbankan tinggi namun indeks literasi produk dan jasa lembaga perbankan rendah seperti yang terdapat pada tabel 1 dan 2.

\section{3) Upaya yang telah dilakukan oleh OJK dan Lembaga Keuangan serta Program Studi untuk meningkatkan Literasi keuangan mahasiswa.}

Guna meningkatkan literasi keuangan di kalangan mahasiswa Otoritas Jasa Keuangan telah melakukan langkah-langkah a) menyelenggarakan pelatihan dalam bisnis keuangan kepada para mahasiswa Indonesia yang ingin meningkatkan kualitas hidup masa depan mereka; b) Menggandeng perusahaan-perusahaan besar seperti PT Sun Life Financial Indonesia ("Sun Life", "Perusahaan") dan Financial Planning Standards Board Indonesia ("FPSB Indonesia") untuk menyelenggarakan program edukasi finansial bagi para mahasiswa melalui program CSR; c) memberikan informasi dan edukasi kepada masyarakat, ibu rumah tangga, siswa sekolah mulai dari Sekolah Dasar, menengah sampai Perguruan Tinggi atas karakteristik sektor jasa keuangan, layanan, dan produknya. Program Studi juga telah menyelenggarakan 
mata kuliah yang berkaitan dengan hal ini seperti bank dan lembaga keuangan dan pasar modal. Namun kedua mata kuliah ini bukan mata kuliah wajib, hanya merupakan mata kuliah pilihan sehingga tidak semua mahasiswa mengambil kedua mata kuliah tersebut.

4) Masukan bagi Otoritas Jasa keuangan maupun Program Studi dalam menyusun materi Literasi keuangan yang dibutuhkan untuk meningkatkan pemahaman mahasiswa tentang produk dan jasa keuangan.

Otoritas jasa keuangan perlu lebih intensif lagi dalam mempropagandakan program literasi keuangan ini kepada mahasiswa. Berbagai kegiatan telah dilakukan, namun terbukti belum secara luas dapat dipahami oleh seluruh mahasiswa. Oleh karena itu upaya sosialisasi program ini harus merupakan usaha yang dilakukan secara kontinue sehingga tingkat keberhasilannya akan lebih besar.

Untuk meningkatkan literasi keuangan mahasiswa maka Program Studi perlu melakukan perbaikan pembelajaran keuangan dengan inovasi pembelajaran. Hasil penelitian ini juga dapat dijadikan sebagai pijakan dasar pengembangan kurikulum pendidikan pada Fakultas Ekonomi dan Bisnis UNSOED. Kurikulum yang diharapkan mampu untuk menumbuhkan literasi keuangan mahasiswa. Agar edukasi dan sosialisasi Literasi Keuangan dapat dilaksanakan pada mahasiswa Prodi Pendidikan Ekonomi dengan maksimal maka materi Literasi Keuangan hendaknya dimasukkan dalam bahan ajar yang diberikan kepada mahasiswa.

Untuk itu perlu dikaji kembali kurikulum yang berlaku di Prodi Prodi Fakultas Ekonomi dan Bisnis untuk mengidentifikasi mata kuliah-mata kuliah apakah yang relevan dengan materi Literasi Keuangan serta menentukan metode pembelajaran yang sesuai. Jika tidak ada mata kuliah yang relevan maka perlu diadakan mata kuliah yang baru. Hal ini sejalan dengan keharusan prodi untuk selalu memperbaharui kurikulum. Disamping itu perlu juga ditentukan format kegiatan pendukung seperti magang dan company visit agar ilmu yang diperoleh mahasiswa dapat diterapkan pada masyarakat khususnya UMKM guna meningkatkan literasi keuangannya, dengan demikian melalui kegiatan praktek seperti itu, pengetahuan mahasiswa akan lebih cepat bertambah.

\section{2) Kesimpulan}

a) Indeks Literasi keuangan terhadap lembaga keuangan yang ada di Indonesia masih rendah hanya sebesar 4,76 mahasiswa yang well literate.

b) Indeks Utilitas Produk dan Jasa Keuangan pada mahasiswa FEB sebesar 95,24\% sebagian besar pada produk dan jasa perbankan.

c) Penyebab dan hambatan tinggi rendahnya indeks Literasi Keuangan dan utilitas produk dan jasa keuangan di kalangan mahasiswa Fakultas Ekonomi dan Bisnis UNSOED adalah : tidak mendapatkan pendidikan keuangan dari keluarga sejak kecil (80 \%), tidak diajarkan di pendidikan formal sejak kecil (77\%), tidak mendapatkan materi dan pemahaman yang dalam dari mata kuliah yang diperoleh selama kuliah (70\%), serta terbatasnya dana yang diterima dari orang tua sehingga tidak dapat digunakan untuk berinvestasi pada produk dan jasa lembaga keuangan $(93 \%)$

d) Otoritas jasa keuangan perlu lebih intensif lagi dalam mempropagandakan program literasi keuangan kepada 
mahasiswa dengan melakukan kegiatan sosialisasi secara kontinue.

e) Program Studi perlu melakukan perbaikan pembelajaran keuangan dengan inovasi pembelajaran, mengidentifikasi mata kuliah-mata kuliah yang relevan dengan materi Literasi Keuangan, menentukan metode pembelajaran yang sesuai serta meninjau kurikulum kembali.

\section{Daftar Referensi}

Cnaan, Ram A., M.S. Moodithaya., \& Femida Handy. (2012). Financial Inclusion: Lessons from Rural South India. Cambridge University

finance.detik.com,2012, ini dia Negara

Negara paling melek keuangan, diakses tanggal 9 Maret 2015

Lusardi, Annamaria, and Olivia S. Mitchell. 2006. Financial Literacy and Planning: Implications for Retirement Wellbeing, Oxford and New York: Oxford University Press.

2008. Planning and Financial Literacy: How Do Women Fare? American Economic Review, 98 (2): 413-417.

Lusardi, Annamaria, Olivia S. Mitchell, and Vilsa Curto, 2010, Financial Literacy among the Young, Journal Market for Retirement Financial Advice. Oxford

Lusardi, Annamaria, and Olivia S. Mitchell, 2014, The Economic Importance of Financial Literacy: Theory and Evidence, Journal of Economic Literature, 52 (1), 5-44

Lauren E. Willis, 2011, The Financial Education Fallacy, American
Economic Review: Papers and Proceedings 2011, 101:3, 429-434

Moleong, Lexy J. Metodologi Penelitian kualitatif. Penerbit PT Remaja Rosda karya Bandung.

Shafi, Mohammad., \& Ali Hawi Medabesh, 2012, Financial Inclusion in Developing Countries: Evidences from an Indian State. Canadian Center of Science and Education.

Xu, Lisa., dan Bilal Zia. (2012). Financial Literacy around the World - An Overview of the Evidence with Practical Suggestions for the Way Forward. The World Bank: Finance and Private Sector Development. 